\title{
Potentiation of Exocytosis by Phospholipase C-Coupled G-Protein-Coupled Receptors Requires the Priming Protein Munc13-1
}

\author{
Claudia S. Bauer, ${ }^{1}$ Robert J. Woolley, ${ }^{1}$ Anja G. Teschemacher, ${ }^{2}$ and Elizabeth P. Seward ${ }^{1}$ \\ ${ }^{1}$ Department of Biomedical Science, University of Sheffield, Sheffield S10 2TN, United Kingdom, and 2Department of Pharmacology, University of Bristol, \\ Bristol BS3 1TD, United Kingdom
}

The vesicle priming protein Munc13-1 is regulated by diacylglycerol (DAG) and is therefore hypothesized to play a role in the control of neurotransmitter release by phospholipase $\mathrm{C}$ (PLC)-coupled receptors. We combined voltage-clamp recordings of voltage-gated Ca ${ }^{2+}$ channels (VGCCs) and high-resolution capacitance measurements to investigate the mechanism of receptor-mediated modulation of exocytosis in bovine chromaffin cells. Activation of endogenous $\mathrm{H}_{1} \mathrm{G}_{\mathrm{q}}$-protein-coupled receptors $\left(\mathrm{G}_{\mathrm{q}} \mathrm{PCRs}\right)$ by histamine potentiated stimulus-coupled secretion despite concurrently inhibiting $\mathrm{Ca}^{2+}$ influx through VGCCs. Histamine increased the size of the readily releasable pool of vesicles and in particular a subpool of fusion-competent vesicles localized in close proximity to VGCCs. Pharmacological characterization showed that potentiation of exocytosis depended on the activation of PLC but not protein kinase C. Overexpression of wild-type Munc13-1 by adenoviral infection had no effect on histamine-induced potentiation per se, whereas DAG-insensitive Munc13$1^{\mathrm{H} 567 \mathrm{~K}}$ completely abolished it.

This is the first endogenous mammalian $\mathrm{G}_{\mathrm{q}}$ PCR signaling pathway identified that engages Munc13-1 to increase stimulus-coupled secretion by recruiting vesicles to the immediately releasable pool. $\mathrm{G}_{\mathrm{q}}$ PCRs are therefore able to control exocytosis at the level of SNARE (soluble $\mathrm{N}$-ethylmaleimide-sensitive factor attachment protein receptor) complex formation to produce rapid, short-term potentiation of the secretory output of neurons and endocrine cells.

Key words: Munc13-1; chromaffin; exocytosis; GPCR; phospholipase C; calcium channels

\section{Introduction}

G-protein-coupled receptors (GPCRs) modulate $\mathrm{Ca}^{2+}$ dependent exocytosis of neurotransmitters from synaptic vesicles as well as hormone and peptide release from large dense core vesicles (LDCVs) as part of a highly regulated information processing system. GPCRs that couple to $\mathrm{G} \alpha$ subunits of the $\mathrm{G}_{\mathrm{q}} \mathrm{I}_{11}$ type are known in particular for their potentiating effect on exocytosis, although the molecular mechanism is often unidentified (Majewski and Iannazzo, 1998; Gromada et al., 1999; Teschemacher and Seward, 2000). G $\mathrm{G}_{\mathrm{q}}$ PCRs activate phospholipase C- $\beta$ (PLC $\beta$ ) and generate the second messenger inositol 1,4,5trisphosphate $\left(\mathrm{IP}_{3}\right)$ and 1,2-diacyl-sn-glycerol (DAG) by breakdown of phosphatidylinositol 4,5-bisphosphate $\left(\mathrm{PIP}_{2}\right)($ Smrcka et al., 1991). $\mathrm{IP}_{3}$ mobilizes $\mathrm{Ca}^{2+}$ from internal stores elevating resting cytoplasmic $\mathrm{Ca}^{2+}$ activity $\left(\left[\mathrm{Ca}^{2+}\right]_{\mathrm{cy}}\right) . \mathrm{Ca}^{2+}$ together with $\mathrm{DAG}$ can then activate protein kinase $\mathrm{C}$ (PKC). PKC plays an important role in regulation of exocytosis (Majewski and Iannazzo, 1998). It is known to phosphorylate proteins involved in

Received Sept. 26, 2006; revised Nov. 26, 2006; accepted Nov. 29, 2006.

This work was supported by a project grant from the Wellcome Trust (E.P.S.). We gratefully acknowledge Drs. David Yue, Edward Levitan, and Terry Herbert for their generous gift of adenoviral constructs. We also thank Dr. Nils Brose for the Munc13-1-EGFP cDNA.

Correspondence should be addressed to Dr. Elizabeth P. Seward, Department of Biomedical Science, University of Sheffield, Sheffield S10 2TN, UK. E-mail: e.p.seward@sheffield.ac.uk.

D01:10.1523/JNEUROSCI.4201-06.2007

Copyright $\odot 2007$ Society for Neuroscience $\quad$ 0270-6474/07/270212-08\$15.00/0 vesicle docking, priming, and fusion (Turner et al., 1999). Phorbol esters (PEs), which mimic the action of DAG, have been widely used to study the role of PKC in modulation of exocytosis.

These results are under debate since the recent discovery of Munc13 proteins. Initially, three homologs of the Caenorhabditis elegans unc-13 gene product, Munc13-1, -2, and -3, were found in the mammalian brain (Brose et al., 1995), and Munc13-1 was identified as a PE-binding protein that primes synaptic vesicles for exocytosis in neurons (Betz et al., 1998). A more general role for Munc13-1 in secretory cells is now emerging (Ashery et al., 2000; Sheu et al., 2003; Kang et al., 2006). Munc13-1 is thought to unfold and activate syntaxin by displacing Munc18, thereby promoting soluble $N$-ethylmaleimide-sensitive factor attachment protein receptor (SNARE) complex formation and hence vesicle priming (Brose et al., 2004). Munc13-1, like PKC, contains the DAG/PE binding $\mathrm{C}_{1}$ domain, and a single point mutation in $\mathrm{C}_{1}$ $(\mathrm{H} 567 \mathrm{~K})$ renders it DAG-insensitive (Betz et al., 1998). Expression of Munc13-1 ${ }^{\mathrm{H} 567 \mathrm{~K}}$ nearly completely abolishes PEdependent facilitation of synaptic transmission, which was originally attributed to PKC (Betz et al., 1998; Rhee et al., 2002). Moreover, mutant mice expressing DAG-insensitive Munc13$1^{\mathrm{H} 567 \mathrm{~K}}$ die shortly after birth, emphasizing the important role of Munc13-1 in DAG signaling in the nervous system. Unlike in $C$. elegans (Lackner et al., 1999), the endogenous mammalian neurotransmitter systems and receptor signaling pathways that use Munc13-1 to modulate exocytosis remain unknown. It is com- 
monly believed, although never investigated directly, that like PKC, Munc13-1 may be regulated by $\mathrm{G}_{\mathrm{q}}$ PCRs. We have tested this hypothesis directly with the endogenous $\mathrm{H}_{1}$ histamine receptor in neurosecretory chromaffin cells, a well established model system for the study of GPCR-mediated modulation of exocytosis (von Ruden and Neher, 1993; Teschemacher and Seward, 2000; Marley, 2003; Chen et al., 2005). Voltage-clamp recordings were combined with membrane capacitance measurements to examine stimulus-coupled secretion under $\mathrm{G}_{\mathrm{q}} \mathrm{PCR}$ modulation. We show that $\mathrm{H}_{1}$ histamine receptor activation potentiated exocytosis by increasing the size of the readily releasable pool (RRP) of vesicles and that this potentiation depended on the DAG sensitivity of Munc13-1. Munc13-1 therefore is an effective interface allowing PLC-coupled DAG-dependent signaling pathways to directly modulate secretory output.

\section{Materials and Methods}

DNA and adenoviral construction. Full-length cDNA encoding Munc13-1 tagged with enhanced green fluorescent protein (EGFP) at the $\mathrm{C}$ terminus (Munc13-1-EGFP) (for details, see Ashery et al., 1999) was supplied by Nils Brose (MPI for Experimental Medicine, Goettingen, Germany). The diacylglycerol binding deficient Munc13-1 ${ }^{\text {H567K_EGFP was created }}$ according to Betz et al. (1998) using the Stratagene (La Jolla, CA) QuikChangeXL Site-Directed Mutagenesis kit (forward oligo, 5' CTGCACCACGCCGAAGAACTTCGAGGTGTGG-3', and reverse oligo, 3'-CCACACCTCGAAGTTCTTCGGCGTGGTGCAG-5'). Successful mutation was confirmed by DNA sequencing. Adenovirus encoding Munc13-1-EGFP and Munc13-1 ${ }^{\mathrm{H} 567 \mathrm{~K}}$-EGFP were constructed using BD Biosciences (Mountain View, CA) Adeno-X Expression System 2 per protocol. Viral titers were determined on HEK293 cells using the end point dilution assay. The titer for Munc13-1-EGFP was $1.5 \times 10^{8} \mathrm{pfu} / \mathrm{ml}$ and was $3 \times 10^{6} \mathrm{pfu} / \mathrm{ml}$ for Munc13-1 ${ }^{\mathrm{H} 567 \mathrm{~K}}$-EGFP.

Cell culture and infection. Chromaffin cells were isolated from adult bovine adrenal glands as described previously (Teschemacher and Seward, 2000). Freshly isolated cells were cultured in DMEM (catalog \#D6171; Sigma, St. Louis, MO) supplemented with 10\% fetal calf serum (Invitrogen, San Diego, CA), 2 mm GlutaMax (Invitrogen), $0.1 \mathrm{mg} / \mathrm{ml}$ penicillin, $0.1 \mathrm{mg} / \mathrm{ml}$ streptomycin, $0.05 \mathrm{mg} / \mathrm{ml}$ gentamicin, $0.01 \mathrm{~mm}$ 5-fluoro-2'-deoxyuridine, $0.015 \mathrm{~mm}$ cytosine arabinoside (all from Sigma) while being plated on glass coverslips coated with BD Matrigel Matrix (VWR Scientific, West Chester, PA) at a density of $6 \times 10^{5}$ cells $/ \mathrm{cm}^{2}$. One-half of the medium was changed after $18 \mathrm{~h}$ and cells were infected by addition of 1.5-50 $\mu \mathrm{l}$ of viral stock of Munc13-1-EGFP or Munc13-1 ${ }^{\text {H567K }}$-EGFP to the culture medium. This resulted in a transfection efficiency of $30-50 \%$. Possible toxic effects of adenoviral infection were assessed in control experiments using 1-4 $\mu$ l of EGFP adenovirus (provided by T. Herbert, University of Leicester, Leicester, UK), $\mathrm{CaM}_{\mathrm{WT}} / \mathrm{EGFP}$ or $\mathrm{CaM}_{1234} /$ EGFP adenovirus (CaM sequence in EGFPpIRES vector for coexpression; provided by D. Yue, Johns Hopkins University School of Medicine, Baltimore, MD). Those virus stocks had a titer of $6 \times 10^{10} \mathrm{pfu} / \mathrm{ml}$ resulting in a transfection efficiency $>70 \%$. Infected cells were identified and classified by their EGFP fluorescence. Fluorescence was detected using $488 \mathrm{~nm}$ excitation provided by a monochromator (TILL Photonics, Gräfelfing, Germany). The intensity of EGFP emission from individual chromaffin cells was measured with a photomultiplier tube coupled to a variable aperture acquisition window (TILL Photonics). The fluorescence intensity was correlated to the cell size (brightness density, in volts per picofarad), and cells were classified as $\mathrm{dim}$ when brightness density was $<0.05 \mathrm{~V} / \mathrm{pF}$.

Electrophysiology. Electrophysiological data were acquired at room temperature by using a combination of voltage-clamp and membrane capacitance measurements as described previously (Powell et al., 2000). Cells were continuously superfused $(1 \mathrm{ml} / \mathrm{min})$ with external control solution containing the following (in $\mathrm{mM}$ ): $140 \mathrm{NaCl}, 2 \mathrm{KCl}, 5 \mathrm{NaHCO}_{3}$, $1 \mathrm{MgCl}_{2}, 2.5 \mathrm{CaCl}_{2}, 10$ glucose, 10 HEPES, pH $7.25(\mathrm{NaOH})$; osmolarity, $\sim 310$ mOsm. Experiments were performed using the perforated patchclamp configuration to minimize rundown of calcium currents and exo- cytosis, and to ensure a physiological regulation of $\left[\mathrm{Ca}^{2+}\right]_{\mathrm{cy}}$ and $\mathrm{Ca}^{2+}{ }_{-}$ dependent signaling pathways (Seward and Nowycky, 1996; Seward et al., 1996). For this, fire-polished borosilicate glass electrodes (Dow Corning, Midland, MI) coated with Sylgard 184 (Dow Corning) with a resistance of 1-2 $\mathrm{M} \Omega$ were filled with internal solution containing the following (in mM): 140 Cs-glutamate (Calbiochem, La Jolla, CA; Merck Biosciences, Darmstadt, Germany), 10 HEPES, $8.5 \mathrm{NaCl}$, 0.3 BAPTA (Invitrogen), and 150-250 $\mu \mathrm{g} / \mathrm{ml}$ gramicidin D (Sigma), pH 7.3 (CsOH; ICN Biomedicals, Aurora, OH); osmolarity, 300 mOsm. Experiments were started once the series resistance was $<15 \mathrm{M} \Omega$ and compensated to $70 \%$ electronically using a patch-clamp amplifier (Axopatch 200B; Molecular Devices, Foster City, CA). Voltage protocol generation, data acquisition, and off-line data analysis were performed using custom-made software (kindly provided by Dr. A. P. Fox, University of Chicago, Chicago, IL). Changes in membrane capacitance $\left(\Delta C_{\mathrm{m}}\right)$ were measured using the software-based phase-tracking method relative to a $100 \mathrm{fF}$ calibration signal (Seward et al., 1995). Capacitance measurements were interrupted to stimulate cells with depolarizing voltage steps from a holding potential of $-80 \mathrm{mV}$ to a test potential of +20 or $+14 \mathrm{mV}$. No corrections were made for liquid junction potentials. $I_{\mathrm{Ca}}$ was not leak subtracted and only cells with a leak current $<15 \mathrm{pA}$ were included in the analysis. Peak $I_{\mathrm{Ca}}$ (in picoamperes) was detected and calcium entry was quantified by integration. The left integration limit was set at $3 \mathrm{~ms}$ into the voltage pulse to exclude $\mathrm{Na}^{+}$current, the right limit was set to exclude tail current. Stimulus-evoked synchronous release was measured as $\Delta C_{\mathrm{m}} 40 \mathrm{~ms}$ after the end of the stimulus (Teschemacher and Seward, 2000); stimulus-independent asynchronous release $1.5 \mathrm{~s}$ later. Each cell was stimulated three to four times before addition of histamine. Basal $\left[\mathrm{Ca}^{2+}\right]_{\mathrm{cy}}$ before application of histamine was not remarkably increased $(3.5 \pm 2.3 \% ; n=11)$ compared with $\left[\mathrm{Ca}^{2+}\right]_{\mathrm{cy}}$ before repetitive stimulation. The exocytotic efficiency $\left(\Delta C_{\mathrm{m}} / \int \mathrm{Ca}^{2+}\right.$ influx $)$ and the $\mathrm{Ca}^{2+}$ influx before application of histamine were averaged and normalized to $100 \%$, respectively.

Double pulse experiments according to Gillis et al. (1996) and Voets et al. (1999) were performed to measure the RRP. Cells were stimulated every $35 \mathrm{~s}$ with two consecutive depolarizing pulses from -80 to $+20 \mathrm{mV}$ (first pulse) or $+14 \mathrm{mV}$ (second pulse) of $100 \mathrm{~ms}$ duration (interpulse interval, $100 \mathrm{~ms}$ ). The depolarizing potentials were selected to give rise to quantitatively equivalent maximal $I_{\mathrm{Ca}}$ counterbalancing calciumdependent inactivation between the first and second stimulus. The RRP size was calculated from the evoked capacitance changes $\left[\Delta C_{\mathrm{m} 1}+\Delta C_{\mathrm{m} 2}\right.$ l $1-R^{2}$ (with $R=\Delta C_{\mathrm{m} 2} / \Delta C_{\mathrm{m} 1}$ )]. Only cells with $R<0.7$ were analyzed because pool size depletion is essential for accurate pool size estimation (Voets et al., 1999). Under control conditions, $50 \%$ of the tested cells ( $n=10)$ showed pool size depletion $(R=0.57 \pm 0.05 ; n=5)$ and the $R$ value was not significantly changed after addition of histamine $(R=$ $0.41 \pm 0.04 ; p=0.089$ ).

To further characterize the different pools of release-competent vesicles, cells were stimulated with a train of $6 \times 10 \mathrm{~ms}$ depolarizations $(390$ $\mathrm{ms}$ interpulse interval) followed by $4 \times 100 \mathrm{~ms}$ depolarizations $(300 \mathrm{~ms}$ interpulse interval) according to Voets et al. (1999). The sum of $\Delta C_{\mathrm{m}}$ induced by the first six stimuli $\left(\Delta C_{\mathrm{m}}\right.$ stim 1-6) represents secretion from the immediately releasable vesicle pool (IRP), whereas the sum of $\Delta C_{\mathrm{m}}$ induced by the following $4 \times 100 \mathrm{~ms}\left(\Delta C_{\mathrm{m}}\right.$ stim7-10) represents secretion of the remaining readily releasable plus part of the slowly releasable pool (SRP) of secretory vesicles (RRP/SRP).

All data are expressed as mean \pm SEM and were collected in each case from at least three different batches of cultured cells. Statistical significance was determined with Student's paired or unpaired $t$ test (SigmaPlot).

Drug application. All drugs were dissolved in $\mathrm{H}_{2} \mathrm{O}$ or DMSO to obtain $\geq 1000$-fold stock solutions and stored as aliquots at +4 or $-20^{\circ} \mathrm{C}$. Drugs were diluted into the external solution immediately before the experiment. Calphostin C, 1-[6-((17 $\beta$-3-methoxyestra-1,3,5(10)-trien-17yl)amino)hexyl]-1 $H$-pyrrole-2,3-dione (U-73122), and 1-[6-((17 $\beta$-3methoxyestra-1,3,5(10)-trien-17-yl)amino)hexyl]-2,5-pyrrolidine-dione (U-73443) were each applied for at least $5 \mathrm{~min}$ before addition of histamine. Bisindolylmaleimide I (Bis) was applied for 20-60 min before histamine. Histamine was purchased from Sigma; PMA, bisindolylmale- 
imide I hydrochloride, U-73122, U-73443, and calphostin $\mathrm{C}$ were from Calbiochem.

$\left[\mathrm{Ca}^{2+}\right]_{\text {cyt }}$ measurements. Chromaffin cells were loaded at $37^{\circ} \mathrm{C}$ with $5 \mu \mathrm{M}$ fura-2 AM (Invitrogen) for $30 \mathrm{~min}$, and then washed for 15 min. Cytoplasmic $\mathrm{Ca}^{2+}$ activity $\left(\left[\mathrm{Ca}^{2+}\right]_{\mathrm{cy}}\right)$ was ratiometrically measured as described by $\mathrm{Te}$ schemacher and Seward (2000) and displayed as the ratio of fluorescence intensity at $340 / 380$ $\mathrm{nm}\left(R_{340 / 380}\right)$.

\section{Results}

Histamine potentiates stimulus-coupled exocytosis by increasing the size of the readily releasable pool of vesicles

Cells were voltage-clamped in the perforated-patch configuration and $\mathrm{Ca}^{2+}$-dependent exocytosis was evoked every $25 \mathrm{~s}$ with brief depolarizing pulses. Vesicle fusion was monitored from changes in membrane capacitance $\left(\Delta C_{\mathrm{m}}\right)$ and $\mathrm{Ca}^{2+}$ entry was measured by recording voltage-gated $\mathrm{Ca}^{2+}$ currents $\left(I_{\mathrm{Ca}}\right)$. At the start of each experiment, the pulse duration was adjusted (25-100 $\mathrm{ms})$ to elicit reproducible $\Delta C_{\mathrm{m}}$ of $\sim 100 \mathrm{fF}$. This lowfrequency stimulus protocol resembles resting "breed and feed" conditions rather than the high-frequency stress stimulation associated with activation of the "fight or flight" response (Fulop et al., 2005) and avoids depletion of release competent vesicles and activity-dependent increases in vesicle priming caused by elevated basal $\left[\mathrm{Ca}^{2+}\right]_{\mathrm{cy}}$ and $\mathrm{PKC}$ activation and changes in the exocytotic efficiency (Engisch et al., 1997; Smith et al., 1998) and is therefore suitable for studying the mechanism underlying $\mathrm{G}_{\mathrm{q}} \mathrm{PCR}$-mediated regulation of exocytosis (Teschemacher and Seward, 2000).

Activation of $\mathrm{H}_{1}$ receptors by superfusion with histamine inhibited peak $I_{\mathrm{Ca}}$ (Fig. $1 \mathrm{~A}$ ) and significantly reduced $\mathrm{Ca}^{2+}$ influx by $20 \%$ (Fig. $1 B$ ). Histamine had no effect on the holding current used to clamp the cells at $-80 \mathrm{mV}\left(I_{\text {Hold }}\right.$ was $-15 \pm 1 \mathrm{pA}$ before and $-14 \pm 2 \mathrm{pA}$ in the presence of histamine; $n=9$ ). The reduction of $I_{\mathrm{Ca}}$ by histamine was attenuated by a short depolarizing prepulse to $+100 \mathrm{mV}$ (data not shown), a hallmark of G-protein modulation of voltage-gated calcium channels (VGCCs) (Dolphin, 2003). Despite the reduction in $\mathrm{Ca}^{2+}$ entry, histamine simultaneously caused a dramatic increase in depolarization-coupled $\Delta C_{\mathrm{m}}$ (Fig. $1 A$ ), corresponding to a $400 \%$ increase in exocytotic efficiency (calculated $\Delta C_{\mathrm{m}} /$ $\int \mathrm{Ca}^{2+}$ influx) (Fig. 1C). The effects of histamine on $I_{\mathrm{Ca}}$ and secretion reversed during washout of the agonist.

A potentiation in exocytotic efficiency could result either from an increase in the number of primed vesicles available for release or from a shift in the $\mathrm{Ca}^{2+}$ dependence of exocytosis. To distinguish between these possibilities, we adopted the double pulse protocol described by Gillis et al. (1996) and Voets et al. (1999) for measuring the size of the RRP in chromaffin cells. As A
B C

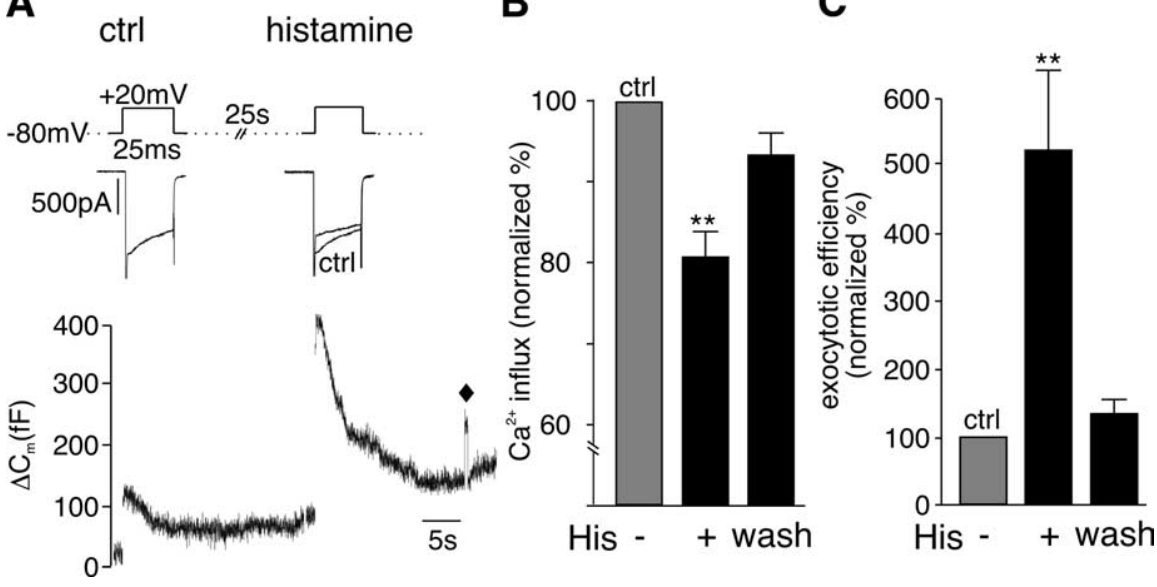

Figure 1. Histamine potentiates stimulus-coupled exocytosis in bovine chromaffin cells. $\boldsymbol{A}$, Representative traces of $I_{\mathrm{Ca}}$ (top) evoked by depolarizations before (ctrl) and during superfusion of histamine (100 $\mu \mathrm{m})$. Corresponding membrane capacitance detection was interrupted during depolarization (gap in $\Delta C_{\mathrm{m}}$ trace), and $\Delta C_{\mathrm{m}}$ was quantified relative to a $100 \mathrm{fF}$ calibration step (indicated by $\boldsymbol{\nabla}$ ). $\boldsymbol{B}, \boldsymbol{C}$, Mean data \pm SEM from $n=13$ cells summarizing the effect of histamine $(100 \mu \mathrm{m})$ on $\mathrm{Ca}^{2+}$ entry $(\boldsymbol{B})$ and exocytotic efficiency $(\boldsymbol{C})$. Data were normalized to control measurements made before application of histamine. The effects of

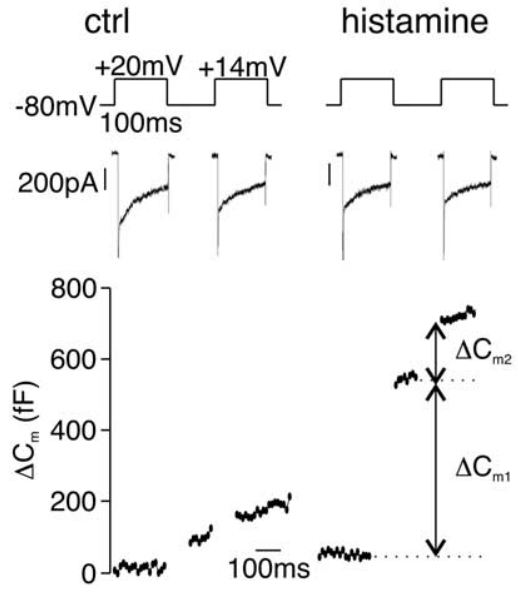

B
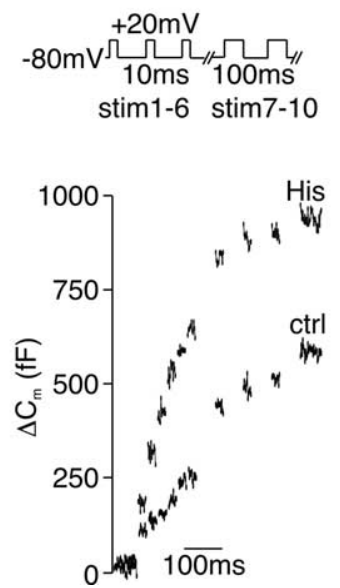

C

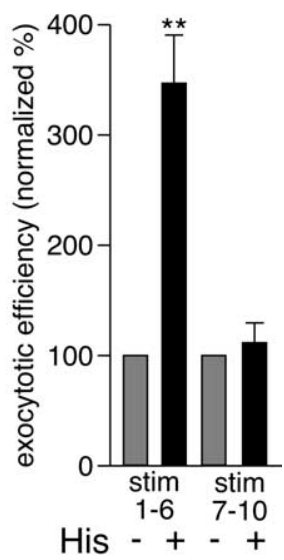

Figure 2. Histamine increases the size of the RRP of vesicles. $A$, Sample traces of $I_{\mathrm{Ca}}$ (top) evoked by the double pulse protocol illustrated used to measure the RRP (100 ms interpulse interval). Corresponding $\Delta C_{\mathrm{m} 1}$ and $\Delta C_{\mathrm{m} 2}$ (bottom) measured in the same cell before and during application of histamine $(100 \mu \mathrm{m})$. $\boldsymbol{B}$, Sample traces of $\Delta C_{\mathrm{m}}$ evoked by a train of $6 \times 10 \mathrm{~ms}(390 \mathrm{~ms}$ during application of histamine $(100 \mu \mathrm{m})$. C, Mean \pm SEM from $n=10$ cells summarizing the effect of histamine on the exocytotic efficiency of a train of $6 \times 10 \mathrm{~ms}$ followed by $4 \times 100 \mathrm{~ms}$ depolarizations. The exocytotic efficiency was calculated as $\Sigma \Delta C_{\mathrm{m}} / \Sigma \int \mathrm{Ca}^{2+}$ for stimulus $1-6$ and stimulus $7-10 .{ }^{* *} p<0.01$.

shown in Figure $2 \mathrm{~A}$, histamine caused a significant increase in the size of the RRP from $290 \pm 85$ to $805 \pm 214 \mathrm{fF}(p=0.037)$ consistent with the view that activation of the receptor increased vesicle priming.

The RRP contains a subpool of vesicles that are released by short depolarizations and hence thought to be located close to VGCC (Voets et al., 1999). We assessed the contribution of this IRP to the effects of the agonist by stimulating cells with a train of six $10 \mathrm{~ms}$ depolarizations. Those stimuli were followed by four $100 \mathrm{~ms}$ depolarizations to elicit secretion of the remaining RRP and probably of a small fraction of the SRP (Voets et al., 1999, 2001). As illustrated in Figure $2 B$, histamine caused a potentiation of depolarization-coupled $\Delta C_{\mathrm{m}}$ in response to the short 
stimuli (stim 1-6) but not the longer depolarizations (stim 7-10) and the exocytotic efficiency was significantly increased (Fig. 2C) during stim 1-6. It would therefore appear that activation of the $\mathrm{H}_{1}$ receptor specifically and exclusively increases priming of vesicles localized close to VGCC to increase stimulus-coupled secretion.

\section{Potentiation of exocytosis by histamine depends on activation} of PLC but not PKC

We next examined the signaling pathway used by histamine to modulate exocytosis. Inhibition of PLC with U-73122 (1 $\mu \mathrm{M})$ blocked histamine-induced potentiation of exocytotic efficiency $(130 \pm 20 \% ; n=5)$. The inactive analog U-73443 (1 $\mu \mathrm{M})$ was without effect (exocytotic efficiency in presence of histamine plus U-73443 was $560 \pm 70 \% ; n=4$ ), suggesting that the inhibitor was acting specifically. Activated PLC generates the second messengers $\mathrm{IP}_{3}$ and DAG. $\mathrm{IP}_{3}$-induced $\mathrm{Ca}^{2+}$ release from stores is known to be required for histamine potentiation of secretion (von Ruden and Neher, 1993; Pan and Fox, 2000); the role of DAG-regulated proteins such as PKC is unclear (Zhang et al., 1995; Donald et al., 2002). The functionality of PKC and of alternative nonkinase DAG receptors is reported to be severely impaired by the C1-domain antagonist calphostin C (Brose and Rosenmund, 2002). We found that pretreatment of the cells with calphostin $\mathrm{C}$ blocked the histamine-induced increase in exocytotic efficiency (Fig. 3A). In contrast, Bis, a specific inhibitor of PKC that acts at the ATP binding site, was completely ineffective (Fig. 3A). VGCCs are known targets for PKC and activation of $\mathrm{PKC}$ by phorbol esters is reported to alter the size and kinetics of $I_{\mathrm{Ca}}$ (Yang and Tsien, 1993; Zhu and Ikeda, 1994); we therefore checked whether the inhibition of PKC by Bis was effective in our cells by examining modulation of $I_{\mathrm{Ca}}$ by PMA. In the same cells that Bis was ineffective at blocking histamine-induced potentiation of secretion, it was effective in preventing PMA-induced changes in $I_{\mathrm{Ca}}$ (Fig. $3 B$ ), demonstrating that the drug was active. Together, our pharmacology data indicate that histamineinduced potentiation of stimulus-coupled exocytosis depends on the activation of PLC and a downstream DAG receptor other than PKC. These results are in agreement with previous biochemical studies on histamine-evoked catecholamine release in unclamped chromaffin cells in which similar differences between the effectiveness of inhibitors that act at the kinase domain (Donald et al., 2002) versus DAG regulatory domain were also observed (Zhang et al., 1995).

\section{Adenoviral infection had no detrimental effect on stimulus- coupled exocytosis and $\mathrm{H}_{1}$ receptor signaling}

To investigate a possible role of the DAG-regulated priming protein Munc13-1 in $\mathrm{G}_{\mathrm{q}} \mathrm{PCR}$ modulation of exocytosis, we wanted to use a dominant-negative strategy that would specifically interfere with the activation of this protein by the receptor-coupled signaling pathway in otherwise uncompromised cells. For this, the DAG-insensitive mutant Munc13-1 ${ }^{\mathrm{H} 567 \mathrm{~K}}$ was expressed in chromaffin cells using adenoviral infection. Experiments were done in parallel with EGFP-tagged wild-type Munc13-1 and EGFP. To assess possible negative effects of adenoviral infection itself on cell function, noninfected and culture-matched chromaffin cells expressing the reporter protein EGFP alone were stimulated with different depolarizing protocols and evoked stimulus-coupled secretion assessed (Fig. 4A-C). High expression levels of EGFP are known to reduce $I_{\mathrm{Ca}}$ in chromaffin cells (Thiagarajan et al., 2005), and therefore we restricted our experiments to cells with low EGFP fluorescence (see Materials and Methods). In contrast
A

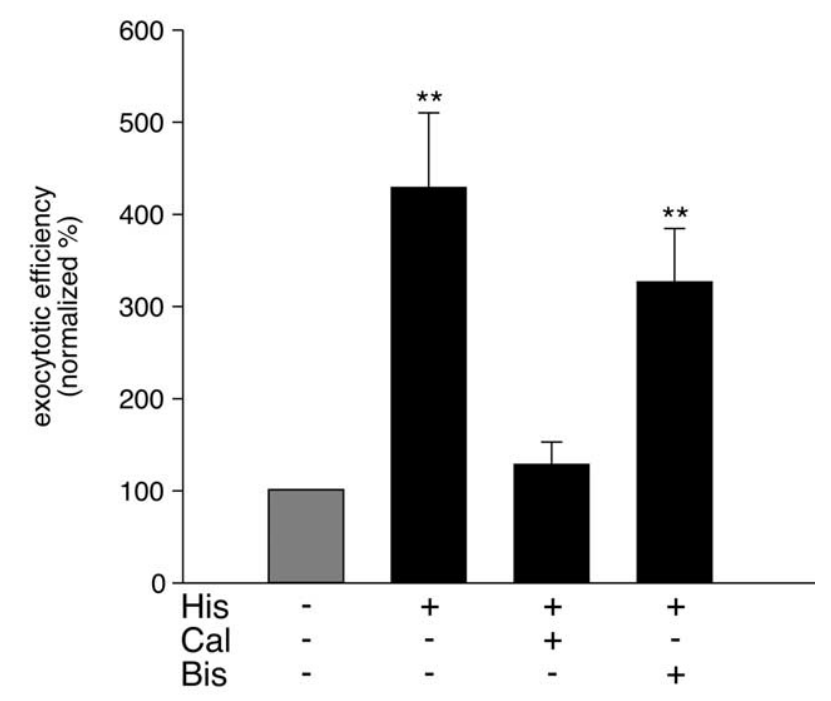

B

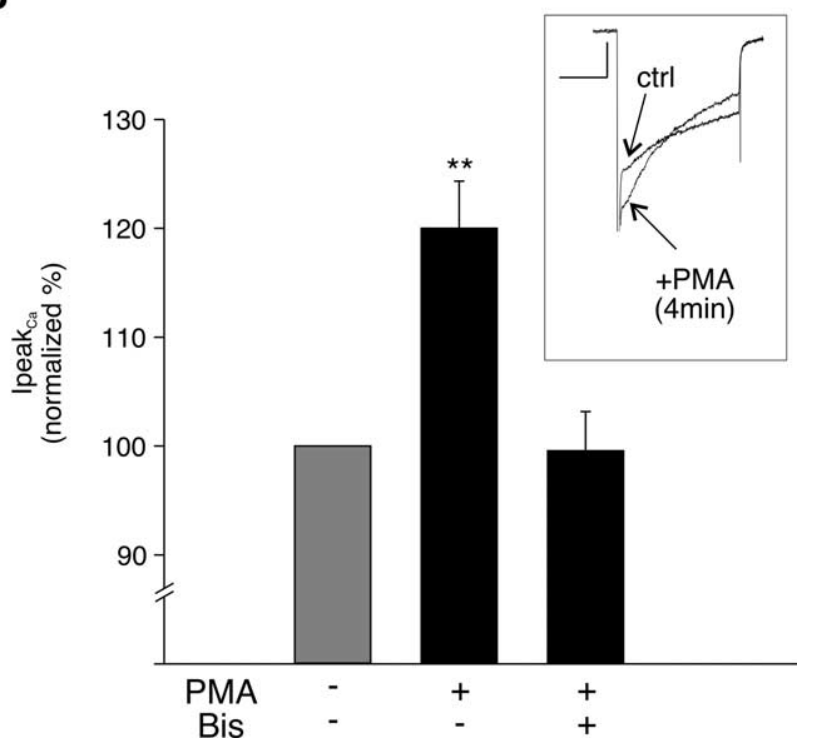

Figure 3. PKC is not involved in histamine potentiation. $A$, Mean data of normalized exocytotic efficiency measured in the presence of histamine (100 $\mu \mathrm{m} ; n=19)$, calphostin C (Cal) (100 nM) plus histamine $(100 \mu \mathrm{m} ; n=6)$, and Bis $(0.5-1 \mu \mathrm{M})$ plus histamine $(n=7)$. $\boldsymbol{B}$, Inset, Overlaid sample traces of $I_{\mathrm{Ca}_{\mathrm{a}}}$ before (ctrl) and 4 min into PMA ( $250 \mathrm{~nm}$ ) application. Bar graph, Mean \pm SEM percentage change in peak $I_{C a}$ by PMA $(250 \mathrm{nM})$ in untreated $(n=6)$ and Bis $(0.5-1 \mu \mathrm{m})$-treated cells $(n=7)$. Note that the experiment represented in $\boldsymbol{B}$ was performed on the same cells represented in $A$ and confirms the effectiveness of the Bis pretreatment. ${ }^{* *} p<$ 0.01 .

to observations made after Semliki Forest virus infection of chromaffin cells (Ashery et al., 1999; Duncan et al., 1999; Pan et al., 2002), adenoviral infection had no significant effect on stimuluscoupled secretion (Fig. 4A) nor on poststimulus "asynchronous" release (Fig. $4 B$ ). Figure $4 C$ shows that secretion from the different vesicle pools was also not affected by adenoviral infection. $\mathrm{Ca}^{2+}$ handling and $\mathrm{H}_{1}$ receptor signaling were also unaltered in adenoviral infected cells compared with noninfected cells (Fig. $4 D, E)$. Basal $\mathrm{Ca}^{2+}$ levels, peak $I_{\mathrm{Ca}}$, and histamine-induced $\mathrm{Ca}^{2+}$ release from stores were not significantly different in uninfected compared with adenoviral infected cells. Basal $R_{340 / 380}$ in noninfected cells $(n=4)$ was $1.7 \pm 0.2$ compared with $1.5 \pm 0.2(n=$ 13 ) in infected cells. $R_{340 / 380}$ increased after $I_{\mathrm{Ca}}$ to $4.0 \pm 0.4$ in 
noninfected and to $3.9 \pm 0.3$ in infected cells and on His-induced $\mathrm{Ca}^{2+}$ release to $2.4 \pm 0.3$ in noninfected and to $2.8 \pm 0.4$ in infected cells. In uninfected cells, $R_{340 /}$ 380 returned from its peak after store release to the basal level in $168 \pm 18 \mathrm{~s}(n=3)$ compared with $156 \pm 1 \mathrm{~s}$ in infected cells $(n=8)$. Adenoviral infection did neither change the probability to observe histamine potentiation of stimulus-coupled exocytosis $[85 \%$ in infected EGFPexpressing cells $(n=21)$ compared with $80 \%$ in uninfected control cells $(n=11)$ ] nor the size of the response (Fig. $4 E$ ). In summary, adenoviral infection proved to be a gentle and effective method for exogenous gene expression without affecting receptor signaling pathways and $\mathrm{Ca}^{2+}$ handling. By restricting our experiments to cells with low EGFP fluorescence, we not only avoided reduction in $I_{\mathrm{Ca}}$ but also the reported increase in asynchronous release attributed to the expression of viral genes (Thiagarajan et al., 2005).

\section{The ability of Munc13-1 to sense DAG is essential for histamine-induced potentiation of stimulus-coupled secretion}

Bovine chromaffin cells express endogenous Munc13-1 and overexpression of wild-type or DAG-insensitive mutant Munc13-1 ${ }^{\mathrm{H} 567 \mathrm{~K}}$ increases exocytosis (Ashery et al., 2000). In agreement with the work of Ashery et al., we found that cells overexpressing Munc13-1 or Munc13-1 ${ }^{\mathrm{H} 567 \mathrm{~K}}$ after adenovirus infection also responded to a depolarizing stimulus (200 $\mathrm{ms})$ with a significant increase in stimulus-coupled secretion and exocytotic efficiency compared with uninfected control cells (supplemental Fig. 1, available at www.jneurosci.org as supplemental material). This confirms that overexpression of a functionally active Munc13-1 alone is sufficient to increase the size of the RRP of vesicles under basal conditions and that the DAG-sensing ability of Munc13-1 is important for regulating the protein rather than performing its priming function (Stevens et al. 2005).

As shown in Figure 5A, cells overexpressing Munc13-1 responded to histamine with a decrease in $I_{\mathrm{Ca}}$ and potentiation of $\Delta C_{\mathrm{m}}$. In contrast, expression of Munc13-1 ${ }^{\mathrm{H} 567 \mathrm{~K}}$ completely abolished histamine potentation of $\Delta C_{\mathrm{m}}$ but not the inhibition in $I_{\mathrm{Ca}}$ (Fig. 5B). In culture-matched noninfected and Munc13-1overexpressing cells, histamine caused a significant increase of exocytotic efficiency that was completely blocked when Munc13$1^{\mathrm{H} 567 \mathrm{~K}}$ was expressed (Fig. $5 C$ ). In all three groups of cells, $I_{\mathrm{Ca}}$ was inhibited to a similar extent after activation of the $\mathrm{G}_{\mathrm{q}} \mathrm{PCR}$ (Fig. 5D). This indicates that G-protein activation and the initiation of the downstream signaling pathway was still functional in cells expressing Munc13-1 ${ }^{\mathrm{H} 567 \mathrm{~K}}$. Munc13-1 ${ }^{\mathrm{H} 567 \mathrm{~K}}$ also had no effects on calcium release from internal stores or PMA regulation of $I_{\mathrm{Ca}}$
B
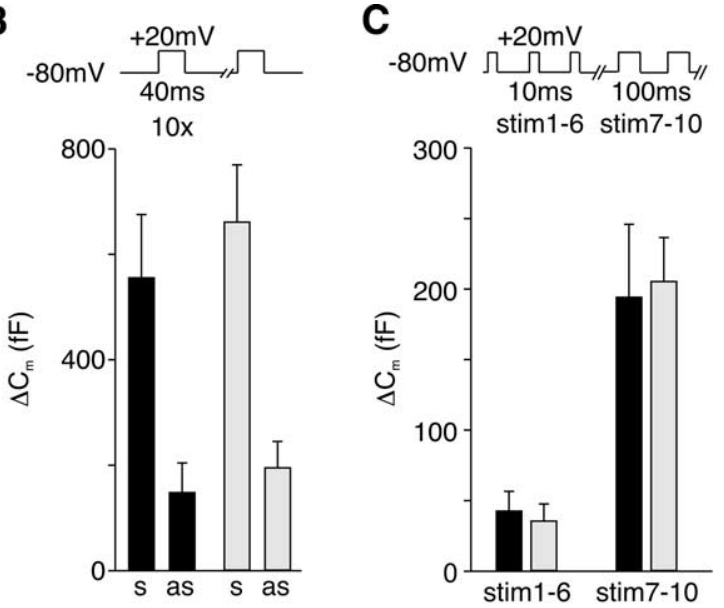

E

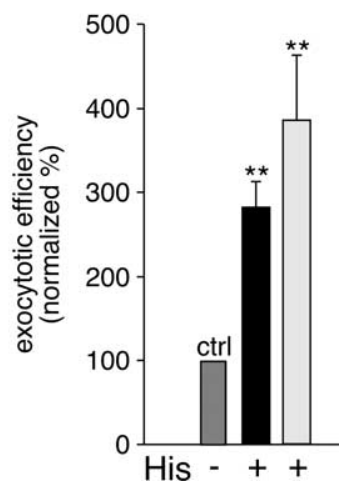

Figure 4. Exogenous gene expression in bovine chromaffin cells using adenovirus. $\boldsymbol{A}$, Mean $\pm \mathrm{SEM}$ peak $I_{\mathrm{Ca}}$ (top) and corresponding membrane capacitance changes $\left(\Delta C_{m}\right)$ (bottom) evoked by a $200 \mathrm{~ms}$ depolarizing pulse from a holding potential of -80 to $+20 \mathrm{mV}$ in noninfected cells $(n=15)$ and culture-matched cells infected with adenovirus for EGFP expression $(n=11)$ , Mean \pm SEM stimulus-coupled synchronous (s) and poststimulus asynchronous (as) $\Delta C_{\mathrm{m}}$ in noninfected (black filled bar; $n=$ (1) IRP) and stimulus 7-10 (remaining RRP and part 作 Sample traces of fura-2 measurements $\left(R_{340 / 380}\right.$; top) and corresponding $\Delta C_{\mathrm{m}}$ (bottom) evoked by 50 ms depolarizing pulses

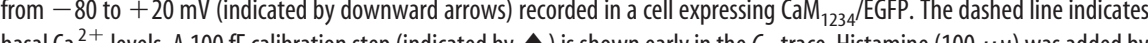
superfusion as indicated. Increase in $C_{m}$ (open arrow) on $\mathrm{Ca}^{2+}$ release from internal stores (filled arrow) was rarely observed ( 3 of 23 noninfected and infected cells). $\boldsymbol{E}$, Mean \pm SEM percentage change in exocytotic efficiency induced by histamine in noninfected cells $(n=8)$ compared with adenoviral infected cells expressing $\operatorname{EGFP}(n=11) .{ }^{* *} p<0.01$.

(data not shown). Thus, expression of the DAG-insensitive Munc13-1 ${ }^{\mathrm{H} 567 \mathrm{~K}}$ selectively abolished the potentiation of exocytosis by histamine without affecting other aspects of receptor signaling.

\section{Discussion}

We used membrane capacitance measurements combined with voltage-clamp recordings to assess directly the effect of agonist and signaling molecules on VGCC function and LDCV priming in chromaffin cells. We show that the DAG signals generated by endogenous $\mathrm{H} 1 \mathrm{G}_{\mathrm{q}} \mathrm{PCR}$ activate Munc13-1 to increase the pool of release-competent vesicles resulting in a short-term potentiation of exocytosis.

Histamine is a neurotransmitter as well as a neuromodulator in the nervous and neuroendocrine system (Schwartz et al., 1991). Its effects on catecholamine secretion, $\mathrm{PIP}_{2}$ turnover, and 
A Munc13-1
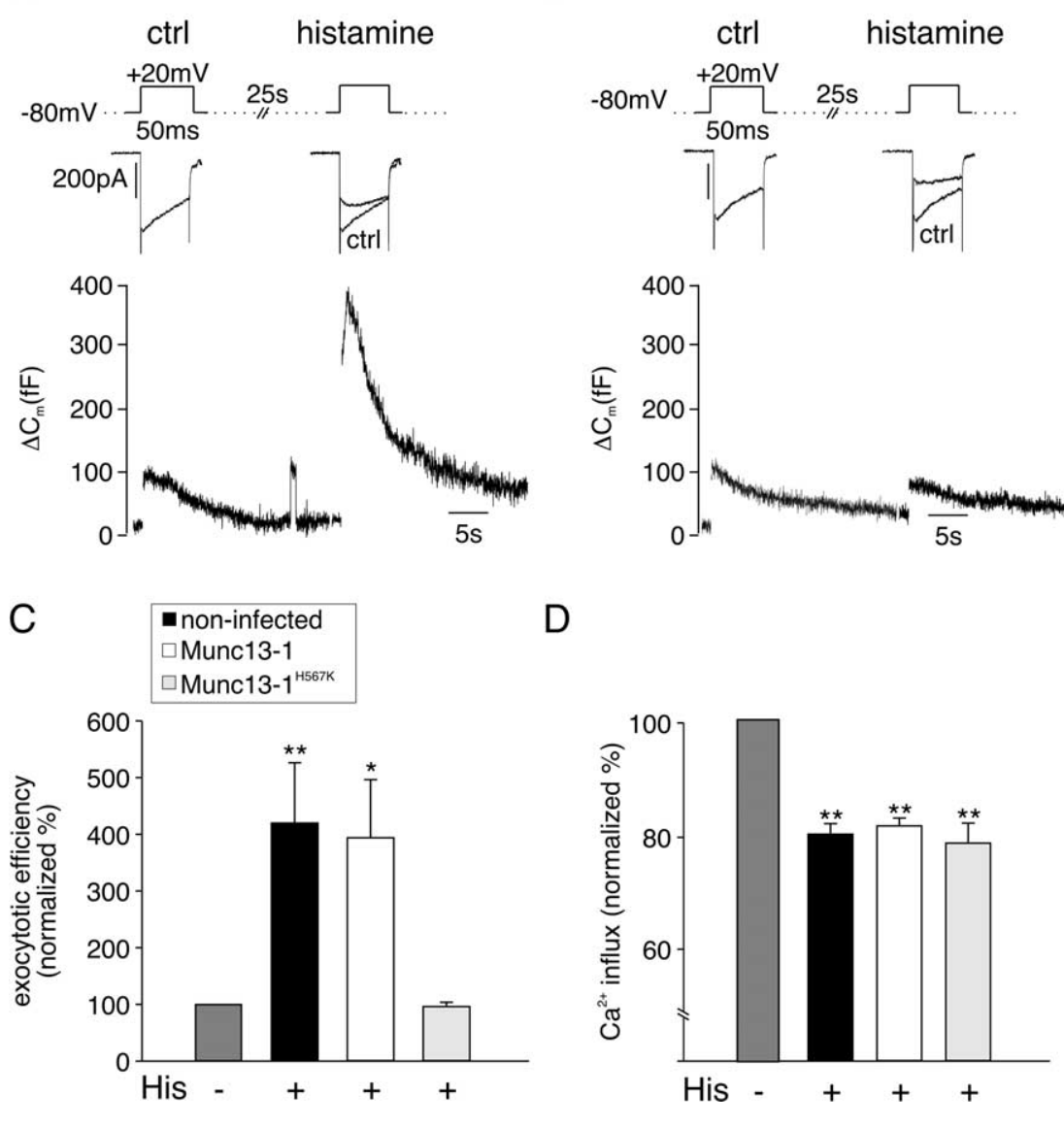

Figure 5. Histamine-induced potentiation of exocytosis is abolished in cells expressing DAG-insensitive Munc13-1 ${ }^{\mathrm{H} 567 \mathrm{~K}}$. $\boldsymbol{A}$, Sample $I_{C_{a}}$ (top) and corresponding $\Delta C_{m}$ (bottom) evoked in an adenovirus-infected chromaffin cell expressing Munc13-1-EGFP before (ctrl) and during superfusion with histamine $(100 \mu \mathrm{m}) . B$, Sample $I_{\mathrm{Ca}}$ (top) and corresponding $\Delta C_{\mathrm{m}}$ (bottom) evoked in an adenovirus-infected chromaffin cell expressing Munc13-1 ${ }^{\mathrm{H} 567 \mathrm{~K}}$-EGFP before (ctrl) and during superfusion with histamine. $\boldsymbol{C}$, Summary of effects of histamine on exocytotic efficiency normalized to (ctrl) for culture-matched, noninfected cells $(n=11)$, Munc13-1-EGFP-overexpressing $(n=10)$, and Munc13-1 ${ }^{\text {H567K }}$-EGFP-expressing $(n=6)$ cells. $\boldsymbol{D}$, Corresponding summary of effects of histamine on normalized $\mathrm{Ca}^{2+}$ entry for the same groups of cells. Error bars indicate SEM. ${ }^{* *} p<0.01 ;{ }^{*} p<0.05$.

potassium channels in chromaffin cells are well documented (von Ruden and Neher, 1993; Zhang et al., 1995; Pan and Fox, 2000; Marley, 2003). Histamine activates $H_{1}$ receptors that couple exclusively to the pertussis toxin-insensitive $\mathrm{G} \alpha_{\mathrm{q}}$ subunit (Hill et al., 1997). With receptor stimulation, $\mathrm{Ca}^{2+}$ influx is inhibited (Fig. 1) in a voltage-dependent way from a direct interaction of $\mathrm{G}_{\beta} \gamma$ subunits with VGCC (Currie and Fox, 2000). This inhibition is likely to involve the $\mathrm{G} \beta_{5}$ subunit, which couples almost exclusively to $\mathrm{G} \alpha_{\mathrm{q}}$ and is known to only modestly inhibit VGCC (Garcia et al., 1998; Arnot et al., 2000). G $\beta \gamma$-mediated inhibition of $I_{\mathrm{Ca}}$ is a widespread mechanism to inhibit $\mathrm{Ca}^{2+}$ dependent stimulus-coupled exocytosis (Miller, 1998; Powell et al., 2000). Activation of $\mathrm{G}_{\beta} \gamma$ from $\mathrm{G} \alpha_{\mathrm{i} / \mathrm{o}}$-coupled receptors may also inhibit exocytosis downstream of $\mathrm{Ca}^{2+}$ entry by affecting the activity of SNARE complexes (Blackmer et al., 2005; Chen et al., 2005; Gerachshenko et al., 2005; Photowala et al., 2006). Here, we find that activation of $\mathrm{G}_{\beta} \gamma$ from $\mathrm{H}_{1}$ receptors is predominantly associated with an increase in priming and exocytosis, indicating that any potential direct inhibitory effects of $G_{\beta} \gamma$ on SNAREs are either prevented (Blackmer et al., 2005) or are $\mathrm{G}_{\beta}$ isoform specific.

Up to now, receptor-mediated Munc13-1 activation in mammalian systems was widely assumed but still speculative (Brose et al., 2004). Our data are the first to show the longstanding hypoth- esis that PLC $\beta$-coupled $\mathrm{G}_{\mathrm{q}} \mathrm{PCR}$ engage Munc13-1 to modulate vesicle priming and hence exocytosis in mammalian cells. At the neuromuscular junction of $C$. elegans, neurotransmitter release is enhanced by a presynaptic signaling pathway containing $\mathrm{G} \alpha, \mathrm{PLC} \beta$, and UNC-13 (Lackner et al., 1999). Mutation of the DAG-binding site in UNC-13 reduces facilitation, indicating that other DAGbinding proteins like PKC or DAGactivated $\mathrm{Ca}^{2+}$ channels may also contribute to the regulation. In contrast to C. elegans, DAG-insensitive Munc13$1^{\mathrm{H} 567 \mathrm{~K}}$ completely abolished the agonistdependent potentiation of exocytosis in chromaffin cells (Fig. 5). Under our conditions, inhibition of PKC had no detectable effect (Fig. 3). It seems, therefore, that the well characterized effect of PKC on the RRP in chromaffin cells is more important for activity-dependent than for receptormediated potentiation of exocytosis (Smith, 1999; Park et al., 2006). We cannot dismiss a possible PKC-mediated modulation of the fusion pore, because this would not necessarily be apparent in $C_{\mathrm{m}}$ measurements. A concerted regulation of vesicle priming and fusion by Munc13-1 and PKC may therefore occur under certain conditions. Experiments on unclamped chromaffin cells report that histamine induces phosphorylation of the syntaxin binding protein Munc18 by PKC and that this is correlated with a change in fusion pore kinetics (Barclay et al., 2003; Craig et al., 2003). A recent report suggests the role of PKC in agonist-dependent regulation of exocytosis may well depend on the presence of other mediators and activation of additional G-protein-coupled signaling pathways (Chen et al., 2005).

$\mathrm{Ca}^{2+}$ release from stores is also required for histamine potentiation of exocytosis (Pan and Fox, 2000); the molecular mechanism of this $\mathrm{Ca}^{2+}$ dependence is unknown but may involve the modulation of Munc13-1 activity by calmodulin (Junge et al., 2004) or DOC2 (Groffen et al., 2006). Interestingly, storedependent $\mathrm{Ca}^{2+}$ influx at the plasma membrane does not appear to be needed for histamine-dependent potentiation of exocytosis because the holding current was not observed to change in the presence of agonist. This is in contrast to results obtained with angiotensin II and may be important in recruitment of additional signaling molecules, such as PKC by AT-1 receptors (Teschemacher and Seward, 2000).

In chromaffin cells, fusion-competent primed vesicles represent only a fraction of vesicles docked at the plasma membrane, suggesting that priming is a limiting process (Ashery et al., 2000). Because chromaffin cells constantly secrete at a low basal activity, limitation of priming may actually play an important physiological role and priming may be strictly regulated to avoid inappropriate and toxic overload of catecholamines in the bloodstream (Aunis and Langley, 1999). Bovine chromaffin cells express Munc13-1 and Munc13-3 (Ashery et al., 2000), and overexpres- 
sion of Munc13-1 increases stimulus-coupled exocytosis by transferring vesicles from a pool of docked but unprimed vesicles to the RRP (Ashery et al., 2000). Low endogenous levels of Munc13-1 and normal secretion from adrenal slices of Munc13-1 knock-out mice led to the assumption that Munc13-1 is not the essential priming protein for LDCVs (Ashery et al., 2000; Stevens et al., 2005). Our data, however, clearly show that DAG-sensitive Munc13-1 is indispensable for the $\mathrm{G}_{\mathrm{q}}$ PCR-mediated short-term potentiation of LDCV secretion. The role of Munc13-3 in chromaffin cells is unclear, but one might speculate that, whereas Munc13-1 acts in receptor-mediated priming, Munc13-3 could cover basal priming. Short-term plasticity in hippocampal neurons depends on the predominant expressed Munc13 isoform (Rosenmund et al., 2002). Whereas Munc13-1-driven synapses show depression during high-frequency stimulation, Munc13-2controlled synapses respond with augmentation. This augmentation is caused by $\left[\mathrm{Ca}^{2+}\right]_{\mathrm{cy}}$-dependent DAG production probably mediated by PLC $\delta$ (Rosenmund et al., 2002; Brose et al., 2004). It was speculated that the ability for depression or augmentation is an intrinsic feature of the respective Munc13 isoform (Rosenmund et al., 2002). We show here that Munc13-1 is necessary for agonist-potentiated exocytosis in chromaffin cells, indicating that a specific modulatory output may arise as a consequence of specific coupling of Munc13 isoforms with PLC isoforms in any given cellular background.

Unlike neurons, chromaffin cells lack molecular defined active zones where exocytosis occurs, but there is mounting evidence for sites of preferred docking and fusion (Schroeder et al., 1994; Oheim et al., 1999; Allersma et al., 2004). These microdomains of release can colocalize with $\mathrm{Ca}^{2+}$ microdomains created on opening of VGCC (Becherer et al., 2003). Not all vesicles within $\mathrm{Ca}^{2+}$ microdomains are released on stimulation, indicating that some vesicles are docked but not primed (Becherer et al., 2003). We previously suggested that during receptor-mediated potentiation of exocytosis, new release sites that had previously been silent become active (Teschemacher and Seward, 2000). It is tempting to speculate that $\mathrm{G}_{\mathrm{q}} \mathrm{PCR}$-mediated activation of Munc13-1 specifically recruits this pool of docked but unprimed vesicles in close proximity to VGCCs, hence the increase in the IRP observed in the presence of agonist (Fig. 2). Even a brief increase of $\left[\mathrm{Ca}^{2+}\right]_{\mathrm{cy}}$ is sufficient to trigger exocytosis and therefore the size of this pool is an obvious target for plasticity.

There is increasing evidence that receptors, their signaling molecules, and their targets colocalize in signaling microdomains (Delmas et al., 2004; Levitan, 2006). The observed membranedelimited modulation of the VGCCs by $\mathrm{H}_{1}$ stimulation, the Munc13-1-mediated DAG dependence of vesicle priming, and the specific priming of vesicles close to VGCCs indicates that $\mathrm{G}_{\mathrm{q}}$ PCRs, VGCCs, and LDCV including their exocytotic machinery might form signaling microdomains dedicated to secretory plasticity. Under resting conditions, the DAG concentration in the plasma membrane is very low and PLC-mediated DAG production is tightly regulated in a spatial and temporal manner (Luo et al., 2004). Like UNC-13, which accumulates at release sites after receptor activation (Lackner et al., 1999), Munc13-1 could be recruited to signaling microdomains during DAG production, prime the residing vesicles and activate previously silent release sites. Because overexpression of wild-type Munc13-1 did not amplify histamine potentiation (Fig. 5), not Munc13-1 but the total number of signaling microdomains might limit the amount of plasticity that can be achieved in the presence of saturating concentrations of agonist. We propose a model in which Munc13-1 initially acts as a scaffold protein to generate and/or stabilize the signaling microdomains in the close proximity of $\mathrm{G}_{\mathrm{q}} \mathrm{PCR} / \mathrm{PLC} \beta$-generated DAG; it then promotes the open configuration of syntaxin molecules localized to these areas of release to trigger SNARE complex formation (Richmond et al., 2001) in these signaling microdomains, ultimately leading to priming of the vesicles docked in close proximity to the $\mathrm{G}_{\mathrm{q}} \mathrm{PCR} / \mathrm{Munc13}-1 /$ VGCC complex. High-resolution imaging experiments of the signaling molecules and vesicle release sites are underway to test this model.

\section{References}

Allersma MW, Wang L, Axelrod D, Holz RW (2004) Visualization of regulated exocytosis with a granule-membrane probe using total internal reflection microscopy. Mol Biol Cell 15:4658-4668.

Arnot MI, Stotz SC, Jarvis SE, Zamponi GW (2000) Differential modulation of N-type 1B and P/Q-type 1A calcium channels by different G protein subunit isoforms. J Physiol (Lond) 527:203-212.

Ashery U, Betz A, Xu T, Brose N, Rettig J (1999) An efficient method for infection of adrenal chromaffin cells using the Semliki Forest virus gene expression system. Eur J Cell Biol 78:525-532.

Ashery U, Varoqueaux F, Voets T, Betz A, Thakur P, Koch H, Neher E, Brose N, Rettig J (2000) Munc13-1 acts as a priming factor for large dense-core vesicles in bovine chromaffin cells. EMBO J 19:3586-3596.

Aunis D, Langley K (1999) Physiological aspects of exocytosis in chromaffin cells of the adrenal medulla. Acta Physiol Scand 167:89-97.

Barclay JW, Craig TJ, Fisher RJ, Ciufo LF, Evans GJ, Morgan A, Burgoyne RD (2003) Phosphorylation of Munc18 by protein kinase C regulates the kinetics of exocytosis. J Biol Chem 278:10538-10545.

Becherer U, Moser T, Stuhmer W, Oheim M (2003) Calcium regulates exocytosis at the level of single vesicles. Nat Neurosci 6:846-853.

Betz A, Ashery U, Rickmann M, Augustin I, Neher E, Sudhof TC, Rettig J, Brose N (1998) Munc13-1 is a presynaptic phorbol ester receptor that enhances neurotransmitter release. Neuron 21:123-136.

Blackmer T, Larsen EC, Bartleson C, Kowalchyk JA, Yoon EJ, Preininger AM, Alford S, Hamm HE, Martin TF (2005) G protein betagamma directly regulates SNARE protein fusion machinery for secretory granule exocytosis. Nat Neurosci 8:421-425.

Brose N, Rosenmund C (2002) Move over protein kinase C, you've got company: alternative cellular effectors of diacylglycerol and phorbol esters. J Cell Sci 115:4399-4411.

Brose N, Hofmann K, Hata Y, Sudhof TC (1995) Mammalian homologues of Caenorhabditis elegans unc-13 gene define novel family of C2-domain proteins. J Biol Chem 270:25273-25280.

Brose N, Betz A, Wegmeyer H (2004) Divergent and convergent signaling by the diacylglycerol second messenger pathway in mammals. Curr Opin Neurobiol 14:328-340.

Chen XK, Wang LC, Zhou Y, Cai Q, Prakriya M, Duan KL, Sheng ZH, Lingle C, Zhou Z (2005) Activation of GPCRs modulates quantal size in chromaffin cells through $\mathrm{G}_{\beta} \gamma$ and PKC. Nat Neurosci 8:1160-1168.

Craig TJ, Evans GJ, Morgan A (2003) Physiological regulation of Munc18/ nSec1 phosphorylation on serine-313. J Neurochem 86:1450-1457.

Currie KP, Fox AP (2000) Voltage-dependent, pertussis toxin insensitive inhibition of calcium currents by histamine in bovine adrenal chromaffin cells. J Neurophysiol 83:1435-1442.

Delmas P, Crest M, Brown DA (2004) Functional organization of PLC signaling microdomains in neurons. Trends Neurosci 27:41-47.

Dolphin AC (2003) G protein modulation of voltage-gated calcium channels. Pharmacol Rev 55:607-627.

Donald AN, Wallace DJ, McKenzie S, Marley PD (2002) Phospholipase $\mathrm{C}$-mediated signalling is not required for histamine-induced catecholamine secretion from bovine chromaffin cells. J Neurochem 81:1116-1129.

Duncan RR, Don-Wauchope AC, Tapechum S, Shipston MJ, Chow RH, Estibeiro P (1999) High-efficiency Semliki Forest virus-mediated transduction in bovine adrenal chromaffin cells. Biochem J 342:497-501.

Engisch KL, Chernevskaya NI, Nowycky MC (1997) Short-term changes in the $\mathrm{Ca}^{2+}$-exocytosis relationship during repetitive pulse protocols in bovine adrenal chromaffin cells. J Neurosci 17:9010-9025.

Fulop T, Radabaugh S, Smith C (2005) Activity-dependent differential transmitter release in mouse adrenal chromaffin cells. J Neurosci 25:7324-7332.

Garcia DE, Li B, Garcia-Ferreiro RE, Hernandez-Ochoa EO, Yan K, Gautam 
N, Catterall WA, Mackie K, Hille B (1998) G-protein $\beta$-subunit specificity in the fast membrane-delimited inhibition of $\mathrm{Ca}^{2+}$ channels. J Neurosci 18:9163-9170.

Gerachshenko T, Blackmer T, Yoon EJ, Bartleson C, Hamm HE, Alford S (2005) $\mathrm{G}_{\beta} \gamma$ acts at the $\mathrm{C}$ terminus of SNAP-25 to mediate presynaptic inhibition. Nat Neurosci 8:597-605.

Gillis KD, Mossner R, Neher E (1996) Protein kinase C enhances exocytosis from chromaffin cells by increasing the size of the readily releasable pool of secretory granules. Neuron 16:1209-1220.

Groffen AJ, Friedrich R, Brian EC, Ashery U, Verhage M (2006) DOC2A and DOC2B are sensors for neuronal activity with unique calciumdependent and kinetic properties. J Neurochem 97:818-833.

Gromada J, Hoy M, Renstrom E, Bokvist K, Eliasson L, Gopel S, Rorsman P (1999) CaM kinase II-dependent mobilization of secretory granules underlies acetylcholine-induced stimulation of exocytosis in mouse pancreatic B-cells. J Physiol (Lond) 518:745-759.

Hill SJ, Ganellin CR, Timmerman H, Schwartz JC, Shankley NP, Young JM, Schunack W, Levi R, Haas HL (1997) International Union of Pharmacology. XIII. Classification of histamine receptors. Pharmacol Rev 49:253-278.

Junge HJ, Rhee JS, Jahn O, Varoqueaux F, Spiess J, Waxham MN, Rosenmund C, Brose N (2004) Calmodulin and Munc13 form a $\mathrm{Ca}^{2+}$ sensor/effector complex that controls short-term synaptic plasticity. Cell 118:389-401.

Kang L, He Z, Xu P, Fan J, Betz A, Brose N, Xu T (2006) Munc13-1 is required for the sustained release of insulin from pancreatic beta cells. Cell Metab 3:1-6.

Lackner MR, Nurrish SJ, Kaplan JM (1999) Facilitation of synaptic transmission by EGL-30 Gqalpha and EGL-8 PLCbeta: DAG binding to UNC-13 is required to stimulate acetylcholine release. Neuron 24:335-346.

Levitan IB (2006) Signaling protein complexes associated with neuronal ion channels. Nat Neurosci 9:305-310.

Luo B, Regier DS, Prescott SM, Topham MK (2004) Diacylglycerol kinases. Cell Signal 16:983-989.

Majewski H, Iannazzo L (1998) Protein kinase C: a physiological mediator of enhanced transmitter output. Prog Neurobiol 55:463-475.

Marley PD (2003) Mechanisms in histamine-mediated secretion from adrenal chromaffin cells. Pharmacol Ther 98:1-34.

Miller RJ (1998) Presynaptic receptors. Annu Rev Pharmacol Toxicol 38:201-227.

Oheim M, Loerke D, Stuhmer W, Chow RH (1999) Multiple stimulationdependent processes regulate the size of the releasable pool of vesicles. Eur Biophys J 28:91-101.

Pan CY, Fox AP (2000) Rundown of secretion after depletion of intracellular calcium stores in bovine adrenal chromaffin cells. J Neurochem 75:1132-1139.

Pan CY, Jeromin A, Lundstrom K, Yoo SH, Roder J, Fox AP (2002) Alterations in exocytosis induced by neuronal $\mathrm{Ca}^{2+}$ sensor-1 in bovine chromaffin cells. J Neurosci 22:2427-2433.

Park YS, Hur EM, Choi BH, Kwak E, Jun DJ, Park SJ, Kim KT (2006) Involvement of protein kinase C- $\varepsilon$ in activity-dependent potentiation of large dense-core vesicle exocytosis in chromaffin cells. J Neurosci 26:8999-9005.

Photowala H, Blackmer T, Schwartz E, Hamm HE, Alford S (2006) G protein $\beta \gamma$-subunits activated by serotonin mediate presynaptic inhibition by regulating vesicle fusion properties. Proc Natl Acad Sci USA 103:4281-4286.

Powell AD, Teschemacher AG, Seward EP (2000) P2Y purinoceptors inhibit exocytosis in adrenal chromaffin cells via modulation of voltage-operated calcium channels. J Neurosci 20:606-616.

Rhee JS, Betz A, Pyott S, Reim K, Varoqueaux F, Augustin I, Hesse D, Sudhof TC, Takahashi M, Rosenmund C, Brose N (2002) Beta phorbol esterand diacylglycerol-induced augmentation of transmitter release is mediated by Munc13s and not by PKCs. Cell 108:121-133.
Richmond JE, Weimer RM, Jorgensen EM (2001) An open form of syntaxin bypasses the requirement for UNC-13 in vesicle priming. Nature 412:338-341.

Rosenmund C, Sigler A, Augustin I, Reim K, Brose N, Rhee JS (2002) Differential control of vesicle priming and short-term plasticity by Munc13 isoforms. Neuron 33:411-424.

Schroeder TJ, Jankowski JA, Senyshyn J, Holz RW, Wightman RM (1994) Zones of exocytotic release on bovine adrenal medullary cells in culture. J Biol Chem 269:17215-17220.

Schwartz JC, Arrang JM, Garbarg M, Pollard H, Ruat M (1991) Histaminergic transmission in the mammalian brain. Physiol Rev 71:1-51.

Seward EP, Nowycky MC (1996) Kinetics of stimulus-coupled secretion in dialyzed bovine chromaffin cells in response to trains of depolarizing pulses. J Neurosci 16:553-562.

Seward EP, Chernevskaya NI, Nowycky MC (1995) Exocytosis in peptidergic nerve terminals exhibits two calcium-sensitive phases during pulsatile calcium entry. J Neurosci 15:3390-3399.

Seward EP, Chernevskaya NI, Nowycky MC (1996) $\mathrm{Ba}^{2+}$ ions evoke two kinetically distinct patterns of exocytosis in chromaffin cells, but not neurohypophysial nerve terminals. J Neurosci 16:1370-1379.

Sheu L, Pasyk EA, Ji J, Huang X, Gao X, Varoqueaux F, Brose N, Gaisano HY (2003) Regulation of insulin exocytosis by Munc13-1. J Biol Chem 278:27556-27563.

Smith C (1999) A persistent activity-dependent facilitation in chromaffin cells is caused by $\mathrm{Ca}^{2+}$ activation of protein kinase C. J Neurosci 19:589-598.

Smith C, Moser T, Xu T, Neher E (1998) Cytosolic $\mathrm{Ca}^{2+}$ acts by two separate pathways to modulate the supply of release-competent vesicles in chromaffin cells. Neuron 20:1243-1253.

Smrcka AV, Hepler JR, Brown KO, Sternweis PC (1991) Regulation of polyphosphoinositide-specific phospholipase $C$ activity by purified $G_{q}$. Science 251:804-807.

Stevens DR, Wu ZX, Matti U, Junge HJ, Schirra C, Becherer U, Wojcik SM, Brose N, Rettig J (2005) Identification of the minimal protein domain required for priming activity of Munc13-1. Curr Biol 15:2243-2248.

Teschemacher AG, Seward EP (2000) Bidirectional modulation of exocytosis by Angiontensin II involves multiple G-protein-regulated transduction pathways in adrenal chromaffin cells. J Neurosci 20:4776-4785.

Thiagarajan R, Wilhelm J, Tewolde T, Li Y, Rich MM, Engisch KL (2005) Enhancement of asynchronous and train-evoked exocytosis in bovine adrenal chromaffin cells infected with a replication deficient adenovirus. J Neurophysiol 94:3278-3291.

Turner KM, Burgoyne RD, Morgan A (1999) Protein phosphorylation and the regulation of synaptic membrane traffic. Trends Neurosci 22:459-464.

Voets T, Neher E, Moser T (1999) Mechanisms underlying phasic and sustained secretion in chromaffin cells from mouse adrenal slices. Neuron 23:607-615.

Voets T, Moser T, Lund PE, Chow RH, Geppert M, Sudhof TC, Neher E (2001) Intracellular calcium dependence of large dense-core vesicle exocytosis in the absence of synaptotagmin I. Proc Natl Acad Sci USA 98:11680-11685.

von Ruden L, Neher E (1993) A Ca-dependent early step in the release of catecholamines from adrenal chromaffin cells. Science 262:1061-1065.

Yang J, Tsien RW (1993) Enhancement of N- and L-type calcium channel currents by protein kinase $\mathrm{C}$ in frog sympathetic neurons. Neuron 10:127-136.

Zhang L, Del Castillo AR, Trifaro JM (1995) Histamine-evoked chromaffin cell scinderin redistribution, F-actin disassembly, and secretion: in the absence of cortical F-actin disassembly, an increase in intracellular $\mathrm{Ca}^{2+}$ fails to trigger exocytosis. J Neurochem 65:1297-1308.

Zhu Y, Ikeda SR (1994) Modulation of $\mathrm{Ca}^{2+}$-channel currents by protein kinase $\mathrm{C}$ in adult rat sympathetic neurons. J Neurophysiol 72:1549-1560. 